
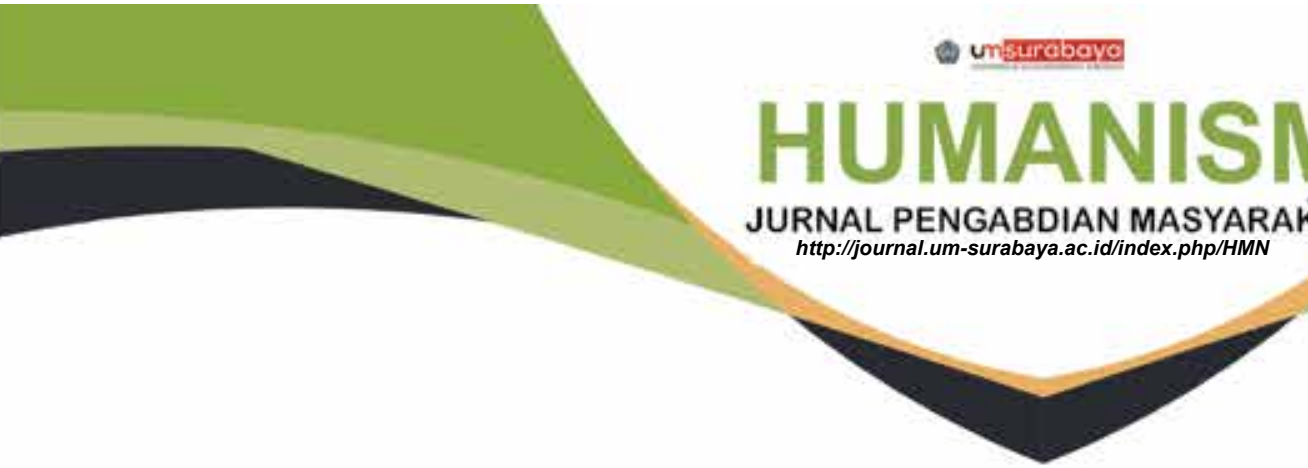

\title{
STRATEGI PEMASARAN BUAH JERUK PETANI \\ MELALUI BUMDES DESA KARANG BUNGA KECAMATAN MANDASTANA
}

\author{
Syafril ${ }^{* 1}$, Yuliani $^{2}$, Hasdi Suryadi ${ }^{3}$ dan Yusuf Asyari ${ }^{4}$ \\ ${ }^{1,2,3}$ ASMI Citra Nusantara \\ ${ }^{4}$ UIN Antasari Banjarmasin \\ Syafril.riau@gmail.com ${ }^{1}$
}

\begin{abstract}
Abstrak
Kegiatan pelatihan ini terselenggara berkat kerjasama antara Tim PINBUK dan Pengelola BUMDES serta Tim Pengembangan Inovasi Desa (PPID) Kabupaten Mandastana. Pembentukan BUMDES sesuai dengan Undang-Undang yang memberikan kewenangan kepada pemerintah desa untuk berinovasi dalam pembangunan desa, terutama untuk meningkatkan perekonomian desa dan kesejahteraan masyarakat desa. Tujuan dari pelatihan ini adalah untuk memberikan pengetahuan dan keterampilan dalam memasarkan produk unggulan desa melalui saluran pemasaran BUMDES dengan teknik bauran pemasaran agar hasil panen jeruk petani menghasilkan keuntungan yang optimal. Metode yang digunakan adalah melakukan presentasi dan diskusi aktif dengan peserta pelatihan. Dampak dari pelatihan ini diharapkan dapat meningkatkan pengetahuan dan keterampilan pemasaran bagi para pelaku UMKM dan BUMDES di Desa Karang Bunga, Kecamatan Mandastana.
\end{abstract}

Kata kunci: BUMDES, Jeruk Siam, Saluran Pemasaran, Bauran Pemasaran, Petani Jeruk 


\section{PENDAHULUAN}

Jeruk siam Banjar (citrus reticulata) asal Kalimantan Selatan merupakan salah satu komoditas unggulan holtikultura yang sangat berkembang dan memiliki prospek yang baik sebagai komoditi yang bernilai ekonomis jika dikelola secara baik dan profesional. Buah jeruk siam banyak digemari karena jeruk ini memiliki kandungan air buah yang tinggi, mempunyai cita rasa buah yang manis dan segar dengan penampilan fisik buah relatif besar, kulit buah luar mengkilap dan mudah dilepas dari daging buah. Warna buah matang kekuningan mengkilap, menjadikan buah ini menjadi pilihan konsumen. Dari beragam jenis buah eksotik khas yang dimiliki Barito Kuala, setidaknya ada satu yang saat ini sedang dibumikan kembali yakni Jeruk Siam Banjar (citrus reticulata). Jeruk Siam Banjar bahkan telah dilepas menjadi varietas unggul nasional. Ini sesuai surat keputusan Menteri Pertanian nomor 862/Kpts/TP.240/11/98.

Sektor pertanian pada saat ini banyak digemari oleh masyarakat Indonesia, sehingga mulai banyak bermunculan pengembangan usaha dibidang pertanian. Saat ini dunia usaha termasuk di dalamnya adalah agribisnis sedang mengalami perubahan dan pertumbuhan yang pesat. Salah satunya adalah pengembangan usaha tanaman pangan dan hortikultura yang mengalami peningkatan cukup signifikan, hal ini dapat dilihat dari semakin banyaknya permintaan pasarakan produk-produk tanaman pangan dan hortikultura. Salah satu komoditas tanaman buah yang menjadi perhatian dalam pengembangan produk pertanian adalah jeruk siam karena memang rasanya manis, tetapi ada juga yang rasanya manis disertai rasa sedikit asam, sehingga bisa menambah rasa segar bila dimakan atau diminum sebagai sari buah (Mandala, Maharani, \& Muwardi, 2016). Budidaya jeruk siam di Desa Karang Bunga Kecamatan Mandastana Kabupaten Barito Kuala memiliki prospek yang sangat cerah, untuk melihat prospek pemasaran agribisnis jeruk siam petani dapat dilakukan melalui BUMDES yang telah berdiri di desa-desa di daerah Kabupaten Barito Kuala.

Permasalahan yang timbul dalam tataniaga jeruk siam antara lain diakibatkan harga sering anjlok pada saat panen. Dengan kondisi seperti ini, maka tataniaga hasil produksi jeruk siam perlu mendapat perhatian, karena walaupun produksi meningkat dalam kuantitas maupun kualitas, apabila tidak diikuti oleh sistem tataniaga yang tepat, maka pendapatan petani akan menurun. Adanya jarak dan waktu dalam tataniaga jeruk siam juga menimbulkan resiko biaya tataniaga. Efesiensi usaha salah satunya ditentukan oleh mekanisme pasar, seperti saluran tataniaga yang dilalui, dan besaran marjin tataniaga (Hidayat, Suslinawati, \& Indriani, 2016). Salah satu alternatif saluran pemasaran bisa dilakukan dengan mengoptimalkan peran BUMDES sebagai pengumpul dan produsen makanan dan minuman berbahan dasar jeruk siam Banjar dari petani di Desa Karang Bunga Kecamatan Mandastana Kabupaten Barito Kuala.

Sudah ada beberapa produk yang telah dihasilkan oleh BUMDES Karang Bunga Kecamatan Mandastana yakni mengolah minuman sari jeruk bermerek JEZLY dan Ice Cream rasa jeruk yang memiliki cita rasa yang segar khas rasa jeruk asli dan manis. Kedua produk yang dihasilkan oleh BUMDES ini tidak kalah rasanya dengan produk sejenis buatan pabrik seperti merk C1000 kemasan botol. Permasalahan dari produk yang dihasilkan adalah pemasaran produk yang 
sangat terbatas jangkauannya. Untuk masalah tersebut maka BUMDES secara langsung mengadakan pelatihan manajemen pemasaran jeruk petani melalui BUMDES yang diikuti oleh peserta dari pelaku UKM dan pengurus BUMDES serta perangkat Desa Karang Bunga Kecamatan Mandastana.

Permasalahan utama dalam pengembangan usaha kecil mikro (UKM) dan Badan Usaha Milik Desa (BUMDES) adalah berkaitan dengan pemodalan, manajemen usaha, pengelolaan keuangan dan pemasaran produk yang dihasilkan. Sebagian besar UKM dan BUMDES terutama skala usaha mikro pada industri rumahan (home industry) masih mengalami masalah dalam memperoleh dan meningkatkan penjualan secara berkesinambungan karena pemasaran produk yang mengandalkan caracara pemasaran konvensional, seperti penjualan melalui pameran, titip barang (konsinyasi) maupun penjualan secara langsung. Dengan manajemen usaha yang dilakukan ini berdampak pada biaya operasional penjualan yang cukup tinggi, perputaran modal menjadi lambat dan terhambatnya proses produksi serta volume penjualan relatif stagnan sehingga menyebabkan peluang dan potensi memperoleh pendapatan dan meraih pangsa pasar menjadi berkurang (Handajani, 2019).

\section{METODE PELAKSANAAN}

\section{Kalayakan Sasaran}

Kegiatan Pengabdian Kepada Masyarakat ini diikuti oleh para pelaku UKM, pengelola BUMDES dan aparat perangkat desa yang ada di Kecamatan Mandastana. Pelatihan ini bertujuan memberikan pengetahuan di bidang saluran pemasaran dan teknik pemasaran produk-produk unggulan desa kepada para pelaku UKM dan pengelola BUMDES agar produk yang dihasilkan dapat dipasarkan baik secara luring maupun secara $\wedge$ daring.

Permasalahan pemasaran yang dihadapi oleh para pelaku UKM dan pengelola BUMDES dalam memasarkan produknya dapat diuraikan dengan teknik bauran pemasaran (marketing mix) yang umumnya dikenal dengan teori 4P yakni Product, Price, Place dan Promotion. Dalam teknik pemasaran mengunakan marketing mix ini, beberapa kendala pemasaran dapat dipecahkan secara sederhana oleh para pelaku UKM dan pengelola BUMDES Kecamatan Mandastana.

Dari paparan permasalahan di atas, Pusat Inkubasi Bisnis Usaha Kecil (PINBUK) Barito Kuala terdorong untuk bekerja sama dengan Tim Program Pengembangan Inovasi Desa (PPID) memberikan pelatihan kepada seluruh PengelolaBUMDES, PelakuUKMdanAparatur Perangkat Desa di 13 (tiga belas) Kecamatan di Kabupaten Barito Kuala. Pelatihan di Kecamatan Mandastana mengambil tema tentang meningkatkan pemasaran jeruk petani melaui BUMDES. Pelatihan ini dimentori oleh PINBUK Barito Kuala yang terdiri dari praktisi dibidang keuangan, ekonomi mikro dengan latar belakang pengalaman di bidang perbankan syariah, pemimpin Baitul Mal Wattamwil (BMT), dan juga akademisi di bidang studi ekonomi, akuntansi, serta manajemen pemasaran yang juga merupakan pengusaha mikro. 


\section{Tahapan Pelaksanaan Pengabdian}

Pengabdian kepada masyarakat ini melalui persiapan yang cukup matang dengan bekerja sama dengan Program Pengembangan Inovasi Desa (PPID) Kecamatan Mandastana bersama tim dari PINBUK Kabupaten Barito Kuala yang terdiri dari praktisi dan akademisi untuk memberikan pelatihan pemasaran produk unggulan melalui BUMDES agar saluran pemasaran tata niaga jeruk di Desa Karang Bunga Kecamatan Mandastana lebih menguntungkan petani dan BUMDES. Perisapan pertama yang dilakukan yakni mengidentifikasi masalah yang terjadi, mempersiapkan materi pelatihan, menjelaskan metode pelatihan, berdiskusi, dan tanya jawab secara langsung dengan memberikan solusi atas permasalahan saluran pemasaran serta evaluasi hasil pelatihan.

\section{Metode Pelaksanaan}

Penyuluhan pengabdian kepada masyarakat ini dilaksanakan di Aula Kecamatan Mandastana Barito Kuala pada hari Rabu, 27 Nopember 2019, dari pukul 09.00 - 17.00 WITA yang dihadiri aparatur Kecamatan, pelaku UKM, Pengelola BUMDES, dan perangkat desa Kecamatan Mandastana.

Metode pelaksanaan pada kegiatan ini dilakukan dengan beberapa metode antara lain:

a. Presentasi (penyampaian teori dan materi secara langsung), pelatihan dilaksanakan dengan menggunakan LCD dan materi disiapkan sesuai dengan solusi permasalahan yang dihadapi oleh pelaku UKM, pengelola BUMDES dan perangkat desa dalam bidang pemasaran produk unggulan desa baik secara offline maupun online.

b. Diskusi, yakni suatu pelatihan dengan melibatkan peserta untuk menyampaikan pendapat maupun permasalahan secara langsung pada saat presentasi dilakukan. Pada saat presentasi dilakukan peserta dapat melontarkan pertanyaan secara langsung agar terjadi dialog interaktif antara pemateri dengan peserta pelatihan.. Dalam penyampaian materi pelatihan, pemateri selalu melibatkan peserta sesuai permasalahan yang mereka hadapi di lapangan sebenarnya.

c. Tanya Jawab, selalu pada saat akhir sesi materi diberikan kesempatan kepada peserta untuk bertanya tentang berbagai hal yang berkaitan dengan materi yang telah dipresentasikan oleh narasumber.

\section{HASIL DAN PEMBAHASAN}

Salah satu kendala bagi pelaku UKM dan pengelola Bumdes adalah bagaimana memasarkan produk-produk yang dihasilkan oleh masyarakat pelaku UKM dan pelaksana Bumdes di desa mereka masing-masing. Banyak keluhan yang disampaikan kepada aparatur pemerintah kecamatan Mandastana bagaimana caranya menjual jeruk yang dihasilkan petani agar memperoleh hasil yang optimal. Untuk itu pemerintah Kecamatan melalui Program Pengembangan Inovasi Desa (PPID) dan BUMDES berkerja sama dengan Pusat Inkubasi 
Bisnis Usaha Kecil (PINBUK) Barito Kuala melakukan pelatihan secara langsung kepada masyarakat. Untuk menunjang pelatihan kami memberikan panduan berupa modul pelatihan yang berisi materi tentang manajemen pemasaran, saluran pemasaran, marketing mix dan peranan BUMDES sebagai pilar ekonomi di desa Karang Bunga dan bagaimana paparan pelaksanaannya.

Permasalahan lain yang timbul dalam tataniaga jeruk siam antara lain diakibatkan harga sering anjlok akibat banyak komoditi buah lain yang masuk ke pasar secara bersamaan, misalnya buah mangga yang dikirim dari Jawa dan buah-buahan lainnya. Dengan kondisi seperti ini, maka tataniaga hasil produksi jeruk siam perlu mendapat perhatian, karena walaupun produksi meningkat dalam kuantitas maupun kualitas, apabila tidak diikuti oleh sistem tataniaga yang tepat, maka pendapatan petani akan menurun. Efesiensi usaha salah satunya ditentukan oleh mekanisme pasar, seperti saluran tataniaga yang dilalui, dan besar kecilnya marjin tataniaga (Hidayat, 2016).

Dengan adanya BUMDES di desa diharapkan terjadi kerjasama dengan pelaku UKM binaan dalam memasarkan produk yang dihasilkan agar penjualan dan pendapatan petani di desa meningkat. Peran BUMDES sebagai motor pengerak ekonomi di desa benarbenar diharapkan berjalan dengan baik sesuai program pemerintah. Kendala yang dihadapi pelaku UKM dan pengelola BUMDES di desa dalam hal pemasaran produk memang bukan perkara yang mudah, banyak hal yang dihadapi seperti permasalahan saluran pemasaran yang jauh dari pasar dan pembeli potensial.
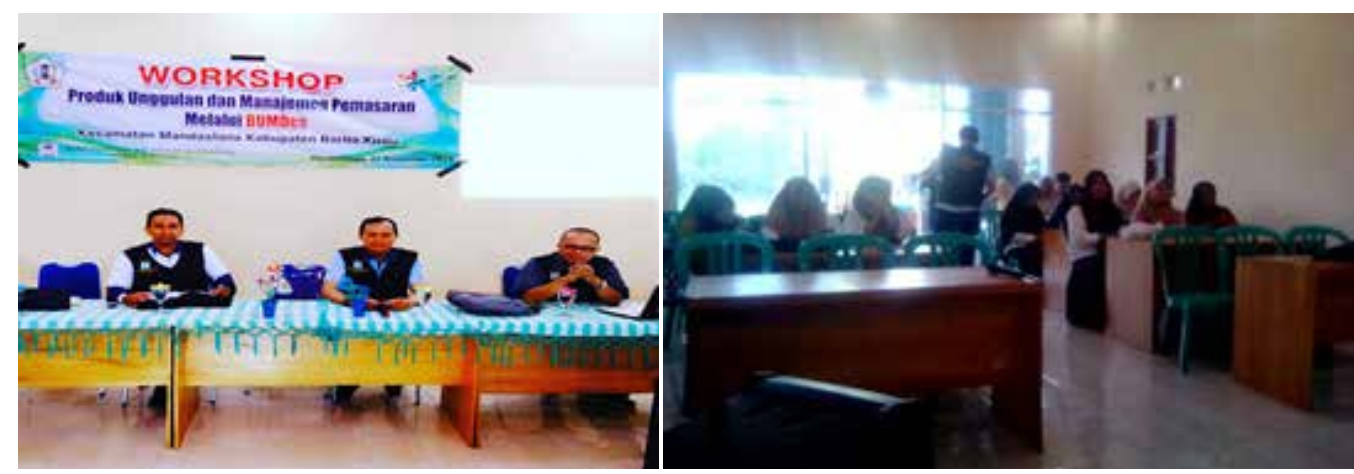

Gambar 1. Narasumber dan Peserta Pelatihan 
Badan Usaha Milik Desa (BUMDES)

BUMDES merupakan institusi yang dibentuk oleh pemerintah desa serta masyarakat mengelola institusi tersebut berdasarkan kebutuhan dan ekonomi desa. BUMDES dibentuk berlandaskan atas peraturan perundang-undang yang berlaku atas kesepakatan antar masyarakat desa. Tujuan BUMDES adalah meningkatkan dan memperkuat perekonomian desa. BUMDES memiliki fungsi sebagai lembaga komersial melalui penawaran sumberdaya lokal yang bertujuan untuk mencari keuntungan dan lembaga sosial melalui kontribusi penyediaan pelayanaan sosial yang berpihak pada kepentingan masyarakat. BUMDES telah memberikan kontribusi positif bagi penguatan ekonomi di pedesaan dalam mengembangkan perekonomian masyarakat khususnya dalam menghadapi Asean Economic Community 2015 (Alkadafi, 2014).

Ciri utama BUMDES yang membedakan lembaga komersial lain (PKDSP, 2007) adalah (1) Badan usaha merupakan milik desa dan pengelolaannya dilakukan secara bersama-sama; (2) Modal usaha sebesar 51\% berasal dari dana desa dan $49 \%$ berasal dari dana masyarakat; (3) Operalisasi dilakukan berdasarkan pada falsafah bisnis berbasis budaya lokal; (4) Potensi yang dimiliki desa dan hasil informasi pasar yang tersedia menjadi dasar untuk menjalankan bidang usaha; (5) Laba yang diperoleh BUMDES dipergunakan untuk upaya peningkatan kesejahteraan anggota dan masyarakat berdasarkan peraturan yang telah disusun; (6)
Fasilitas ditunjang oleh Pemerintah Provinsi, Kabupaten, dan Pemerintah desa; dan (7) Pelaksanaan operasionalisasi BUMDES diawasi secara berasma oleh Pemerintah Desa, BPD beserta anggota (Agunggunanto, 2016).

\section{Manajemen Pemasaran}

Manajemen pemasaran adalah seni dan ilmu untuk memilih pasar sasaran serta mendapatkan, mempertahankan, dan menambah jumlah pelanggan melalui penciptaan, penyampaian, dan pengkomunikasian nilai pelanggan yang unggul. Pemasar adalah seseorang yang mencari tanggapan (perhatian, pembelian, suara, donasi) dari pihak lain, yang disebut prospek (Kotler, 2009). Sedangkan pemasaran adalah suatu proses sosial dan manajerial di mana individu dan kelompok mendapatkan kebutuhan dan keinginan mereka dengan menciptakan, menawarkan dan bertukar sesuatu yang bernilai satu sama lain (Abdullah, 2012).

\section{Saluran Pemasaran}

Menurut Stern dan El-Ansary dalam (Abdullah, 2012), Saluran pemasaran dapat dilihat sebagai sekumpulan organisasi yang saling tergantung satu sama lainnya yang terlibat dalam proses penyediaan suatu produk atau pelayanan untuk digunakan atau dikonsumsi. Banyak produsen berkerja sama dengan perantara pemasaran untuk mengirimkan produk-produknya ke pasar. Perantara pemasaran merupakan salah satu saluran pemasaran (juga disebut saluran perdagangan atau saluran distribusi.

Anggota-anggota dalam saluran pemasaran melakukan beberapa fungsi utama dan berpartisipasi dalam arus pemasaran sebagai berikut: 
a. Informasi; pengumpulan dan penyebaran informasi riset pemasaran mengenai pelanggan potensial dan pelanggan saat ini, pesaing, pelaku dan kekuatan lain dalam lingkungan pemasaran.

b. Promosi; pengembangan dan penyebaran komunikasi persuasif mengenai penawaran yang dirancang untuk menarik pelanggan.

c. Negosiasi; usaha untuk mencapai persetujuan akhir mengenai harga dan syarat-syarat lain sehingga pengalihan kepemilikan dapat dipengaruhi.

d. Pesanan; komunikasi ke belakang yang bermaksud mengadakan pembelian oleh anggota saluran pemasaran kepada produsen.

e. Pendanaan; penerimaan dan pengalokasian dana yang dibutuhkan untuk penyediaan persediaan pada tingkat saluran pemasaran yang berbeda.

f. Pengambilan resiko; asumsi yang terkait dengan pelaksanaan kerja saluran pemasaran.

g. Kepemilikan fisik; gerakan penyimpanan dan pemindahan produk fisik mulai dari bahan mentah hingga produk jadi ke pelanggan.

h. Pembayaran; pembeli yang membayar melalui bank dan lembaga keuangan lainnya kepada penjual.

i. Kepemilikan; pengalihan kepemilikan dari satu organisasi atau individu ke organisasi atau individu lainnya
Saluran pemasaran yang dipilih dalam memasarkan jeruk siam di Kecamatan Mandastana sangat berpengaruh terhadap pendapatan yang diperoleh petani jeruk siam itu sendiri. Selama ini saluran pemasaran oleh petani jeruk siam dalam proses pemasarannya sebelum sampai ke konsumen akhir di wilayah Banjarmasin dan sekitarnya. Gambaran umum saluran pemasarannya sebagai berikut,

1. Petani Pedagang Pengumpul Desa Pedagang Besar Pedagang Pengecer Konsumen Akhir

Dengan adanya BUMDES di Kecamatan Mandastana saat ini maka saluran pemasaran yang ada dapat dimanfaatkan oleh BUMDES sebagai salah satu lini bisnis yakni dengan menjadi perantara petani dalam menyalurkan hasil panen jeruk siam di desadesa di Kecamatan Mandastana. Saluran pemasaran jeruk dari petani sampai ke konsumen akhir menjadi sebagai berikut:

2. Petani $\Rightarrow$ BUMDES $\Rightarrow$ Pedagang Besar Pedagang Pengecer $\Rightarrow$ Konsumen Akhir

2. Petani $\Rightarrow$ BUMDES $\Rightarrow$ Pedagang pengecer $\Rightarrow$ Konsumen Akhir

Saluran pemasaran pada poin 2. memberikan peran kepada BUMDES sebagai perantara pemasaran antara petani dengan pedagang besar dan juga dapat mengolah bahan dasar dari buah jeruk menjadi produk makanan dan minuman seperti sari jeruk merk JEZLY dan ice cream yang saat ini sudah dilakukan oleh BUMDES Kecamatan Mandastana 
walau jumlah produksinya masih dalam skala kecil. Jika produk yang dihasilkan BUMDES dapat bersaing dan diterima di pasaran maka harga jeruk petani bisa lebih stabil dan BUMDES memiliki peluang usaha yang lebih besar dengan mengolah bahan baku jeruk yang tersedia dari petani yang juga anggota BUMDES. Saluran pemasaran yang diambil oleh BUMDES bisa memotong mata rantai agar lebih efisien jika BUMDES memiliki sumber daya manusia yang mampu menjalankan fungsinya sebagai pedagang besar dan menyalurkan langsung ke pedagang eceran di daerah Banjarmasin dan sekitarnya.

\section{Marketing Mix}

Dalam ilmu pemasaran secara luas sudah dikenal dengan teknik bauran pemasaran (Marketing Mix), yaitu Bauran pemasaran adalah variabel - variabel yang dapat dikendalikan oleh perusahaan, yang terdiri dari produk, harga, distribusi, dan promosi (Anoraga 2000:220). Dari definisi di atas dapat diambil kesimpulan pengertian dari marketing mix adalah faktor - faktor yang dikuasai dan dapat digunakan oleh marketing manajer guna memengaruhi penjualan atau bisa juga diartikan sebagai pendapatan perusahaan, faktor - faktor tersebut adalah product, price, place, dan promotion.

Dengan menerapkan marketing mix maka secara perlahan permasalahan pemasaran produk-produk yang dihasilkan pelaku usaha kecil di desa dapat diurai secara benar. Marketing mix secara umum dikenal dengan teori 4P yang merupakan perpaduan dari Product, Price, Place, dan Promotion (Syafril; Madayan;Salahudin Bahri, 2020). Dalam memasarkan produk yang dihasilkan seorang pemasar harus memahami beberapa hal yang melekat pada 4P tersebut seperti pada gambar berikut ini:

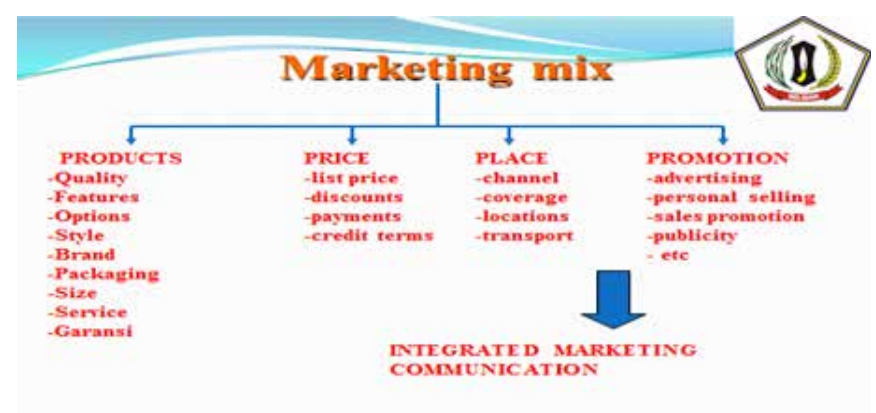

Gambar 3. Marketing Mix Tools

Product

Produk adalah serangkaian keuntungankeuntungan yang disampaikan kepada customer. Produk merupakan segala sesuatu yang dapat ditawarkan produsen untuk diperhatikan, diminta, dicari, dibeli, digunakan, atau dikonsumsi pasar sebagai pemenuhan kebutuhan atau keinginan pasar bersangkuatan, baik berupa barang maupun jasa (Karim, 2014). Beberpa produk yang telah dihasilkan oleh BUMDES Karang Bunga dapat bersaing dari sisi kualitas dan rasa sepeti sari jeruk JELY dan ice cream seperti gambar dibawah ini.

Price

Harga merupakan sejumlah uang sebagai alat untuk membayar produk atau jasa (Kottler,2009; Abdullah, 2012). Dalam menentukan harga jual harus diperhatikan beberapa hal supaya produk dapat bersaing dipasaran seperti pricing strategy (strategi harga), importance of knowing the market (memahami pasar), elasticity (elastisitas), keeping an eye on rivals (menaruh perhatian terhadap kompetitor). 


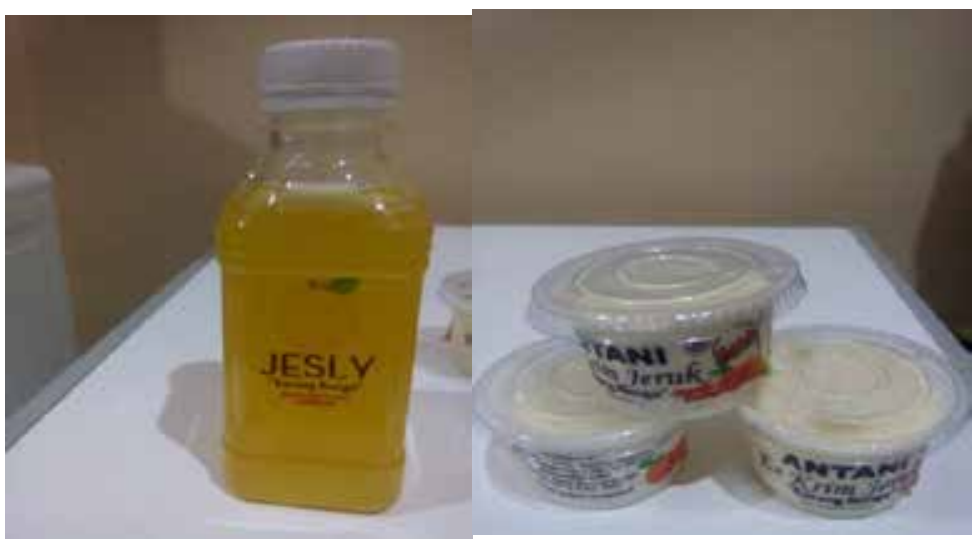

Gambar 4. Sari Jeruk JEZLY dan Ice Cream Rasa Jeruk

Dalam mementukan harga produk yang dihasilkan, BUMDES dapat menerapkan strategi maksimal harga sama dengan produk pesaing sejenis di pasaran yang telah lama beredar.

\section{Place}

Tempat merupakan sarana di mana produk dan jasa dari produsen sampai ke konsumen, atau di mana produk dan jasa tersebut dapat diakses oleh konsumen. Semakin banyak tempat yang mudah untuk mendapatkan atau membeli produk/jasa, semakin baik bagi bisnis dan konsumen. Tempat mengacu pada penyediaan produk pada suatu tempat bagi konsumen, untuk lebih mudah untuk mengaksesnya. Tempat identik dengan distribusi, meliputi masalah pemasaran seperti, jenis saluran, eksposur, transportasi, distribusi, dan lokasi. Sebuah produk harus tersedia kepada konsumen kapan dan di mana konsumen menginginkannya (Karim, 2014).Dalam hal ini pelaku UKM dan BUMDES harus memikirkan tempat mereka berjualan karena secara konvensional tempat sangat berpengaruh terhadap penjualan suatu produk. Kendala utama pemasaran produk UKM dan BUMDES Kecamatan Mandastana dimana lokasi desa cukup jauh dari pasar atau calon pembeli potensial. Salah satu alternatif pemecahan masalah tempat (Place) ini dapat dilakukan dengan cara pemasaran secara online melalui media internet seperti web, marketplace,instagram, whatshap group yang tidak mengenal batas wilayah. Permasalahan ini sudah dipikirkan oleh pemerintah dimana di desa sudah diberikan fasilitas internet dalam Program One Village One Internet Connection kerja sama 2 (dua) kementrian yakni Kementrian Desa dan Pembangungan Wilayah Tertinggal dan Transmigrasi dengan Kementrian Komunikasi dan Informatika yang ditempatkan servernya di setiap Kantor Kecamatan di desa-desa wilayah Kabupaten Barito Kuala.

\section{Promotion}

Promosi adalah suatu bentuk komunikasi pemasaran dalam bentuk aktivitas untuk menyebarkan informasi, mempengaruhi, dan 
mengingatkan pasar sasaran atas perusahaan dan produknya agar bersedia menerima, membeli, dan loyal pada produk yang ditawarkan perusahaan yang bersangkuatan. Strategi promosi digunakan untuk membuat konsumen sadar akan keberadaan produk atau jasa. Promosi adalah komponen pemasaran yang sangatpentingkarena dapatmeningkatkan pengenalan merek dan penjualan. Beberapa metode pemasaran yang dapat dilakukan oleh pelaku UKM dan pengelola BUMDES agar produk yang dihasilkan mendapatkan pembeli yang potensial seperti dengan iklan dan pemasaran tradisional dari mulut kemulut (Syafril;, 2020)

Iklan biasanya mencakup metode komunikasi berbayar seperti iklan televisi, iklan radio, media cetak, dan iklan internet. Di zaman sekarang, tampaknya ada pergeseran dalam fokus offline ke dunia online.

Word of mouth juga merupakan jenis promosi produk. Promosi dari mulut ke mulut adalah komunikasi informal tentang manfaat produk oleh pelanggan yang puas. bagian penjualan memainkan peran yang sangat penting dalam pemasaran dari mulut ke mulut. Pemasaran dengan metode word of mouth juga bisa beredar di internet dalam bentuk viralisasi dan hal ini memiliki potensi untuk menjadi salah satu aset paling berharga yang pelaku usaha miliki dalam meningkatkan laba. Pelaku usaha melalui interaksi melalui media online yang sangat populer saat ini. Jika pelaku usaha memliki berbagai saluran media online yang sedang banyak diminati maka akan semakin terbuka pemasaran produk yang dimiliki.

\section{Marketing Budget}

Untuk memasarkan suatu produk tentu membutuhkan dana pemasaran (marketing budget) yang harus disiapkan oleh pelaku UKM dan pengelola BUMDES yang besarannya tergantung dari media pemasaran yang digunakan. Semakin sering melakukan promosi tentu semakin besar pula dana yang dibutuhkan. Untuk itu pelaku UKM dan pengelola BUMDES harus dapat memilih media yang paling efisien dari segi biaya disesauikan dengan keuntungan yang akan diperoleh. Salah satu promosi yang tepat telah dilakukan Pemerintah Kecamatan Mandastana Barito Kuala yakni dengan rutinnya digelar Festival yang banyak diliput media massa dan dikunjungi oleh turis asing maupun lokal.

Selain itu diperlukan waktu yang pas (timing) dalam melakukan pemasaran yang memberikan efek yang luas terhadap pengenalan dan peningkatan penjualan produk seperti saat ada keramaian di wilayah masing-masing misalnya pada saat perayaan hari ulang tahun Kabupaten Barito Kuala atau Kecamatan Mandastana, festival rakyat atau berbagai even-even yang diselenggarakan pemerintahan baik pusat maupun daerah. Hal ini tentunya berkaitan dengan biaya promosi yang murah agar produk UKM dapat bersaing dipasaran. Efisiensi biaya sangat penting berkaitan dengan penetapan harga jual produk yang ditawarkan kepada calon pembeli potensial. 


\section{Dampak Kegiatan}

Pengertian dampak menurut Kamus Besar Bahasa Indonesia adalah benturan, pengaruh yang mendatangkan akibat baik positif maupun negatif. Pengaruh adalah daya yang ada dan timbul dari sesuatu (orang, benda) yang ikut membentuk watak, kepercayaan atau perbuatan seseorang. Pengaruh adalah suatu keadaan dimana ada hubungan timbal balik atau hubungan sebab akibat antara apa yang mempengaruhi dengan apa yang dipengaruhi. (KBBI Online, 2010).

Menurut Soekidjo Notoatmodjojo (1991) dalam Ekawati (2019) bahwa keberhasilan pelaksanaan suatu program pelatihan dapat dikatakan sukses apabila dalam diri peserta pelatihan tersebut terjadi suatu proses transformasi dalam; (1) Peningkatan kemampuan dalam melaksanakan tugas, (2) Perubahan perilaku yang tercermin pada sikap, disiplin, dan etos kerja. Sedangkan Kaswan (2011) mengemukakan bahwa pelatihan merupakan suatu proses untuk meningkatkan pengetahuan dan keterampilan.

Dari berbagai uraian tentang saluran pemasaran dan teknik bauran pemasaran (marketing mix) yang diberikan pada saat pelatihan peningkatan manajemen pemasaran produk unggulan diharapkan para pelaku UKM dan pengelola BUMDES serta aparatur perangkat desa memiliki pengetahuan tentang berbagai strategi pemasaran agar produk yang dihasilkan mendapatkan pembeli potensial yang secara langsung akan meningkatkan pendapatan (laba) usaha pelaku UKM dan BUMDES. Setelah diberikan pelatihan para pelaku UKM dan BUMDES mulai melakukan evaluasi terhadap proses pemasaran yang mereka lakukan sebelumnya yang dilakukan secara konvensional.

\section{KESIMPULAN}

Dari hasil kegiatan Pengabdian Kepada Masyarakat ini dapat ditarik suatu kesimpulan bahwa kegiatan ini memberikan dampak yang signifikan terhadap pengetahuan pelaku UKM, pengelola BUMDES dan aparatur pemerintahan desa dalam memasarkan produk yang dihasilkan melalui berbagai saluran pemasaran dengan berbagai teknik marketing mix dimana sebelum pelatihan dilaksanakan belum memahami teknik pemasaran tersebut. Pelatihan ini juga memberikan dampat pengetahuan tentang pemasaran produk secara online dengan memanfaatkan fasilitas internet desa yang dibangun pemerintah. Pada awalnya masih banyak pelaku UKM yang belum faham memasarkan produknya secara online melaui media internet di marketplace seperti Bukalapak, Tokopedia dan Shopee.

\section{UCAPAN TERIMA KASIH}

Rasa terima kasih kami ucapkan kepada Pemerintah Daerah Kabupaten Barito Kuala dan Kecamatan Mandastana yang telah memberikan kesempatan kepada kami untuk memberikan pelatihan kepada para pelaku UKM dan pengelola BUMDES. Semoga materi yang telah diberikan setelah kegiatan pengabdian ini dapat diaplikasikan dalam kehidupan sehari-hari dalam menunjang bisnis yang sudah dijalani selama ini. Selain itu kami 
juga berterima kasih kepada seluruh pihak yang terkait seperti LPPM ASMI Citra Nusantara Banjarmasin, UIN Antasari Banjarmasin dan anggota TIM PPID, dan yang lainnya yang tidak bisa disebutkan satu persatu.

\section{REFERENSI}

(PKDSP), P. K. (2007). Panduan Pendirian dan Pengelolaan Badan Usaha Milik Desa (BUMDes). Malang: FE Universitas Brawijaya.

Abdullah, T., \& Tantri, F. (2012). Manajemen Pemasaran. Jakarta: Rajawali Pers.

Agunggunanto; Edy Yusuf; Fitrie Arianti; Edi Wibowo; Darwanto. (2016). Pengembangan Desa MAndiri Melalui Pengelolan Badan Usaha Milik Desa (BUMDes). 13.

Alkadafi. (2014). Penguatan Ekonomi Masyarakat Melalui Pengelolaan Kelembagaan Badan usasha Milik Desa Menuju ASEAN Economic Community 2015. Jurnal El-Riyasah, 32-40.

Handajani, L., Akram, Fukron, L. M., \& Rifai, A. (2019, Desember). Penggunaan Pemasaran Digital Pada Usaha Home Industri Kopi Lombok Di Desa Sigerongan Kabupaten Lombok Barat. Jurnal Abdi Insan LPPM Unram, 6 (3).

Hidayat, M., Suslinawati, \& Indriani, P. (2016, Mei). Analisis Tata Niaga Jeruk Siam Banjar (Citrus Reticulata) Di Desa Karang Buah Kecamatan Belawang Kabupaten Barito Kuala. Jurnal Al Ulum Sains Bisnis dan Teknologi, 1 (2).
Karim, D., Sepang, J. L., \& Lumanauw, B. (2014, Maret). Marketing Mix Pengaruh Terhadap Volume Penjualan Pada PT Manado Sejati Perkasa Group. Jurnal EMBA, 2 (1), 421-430.

Kaswan. (2011). Pelatihan dan Pengembangan. Bandung: PT Alfabeta.

Kottler, P., \& Keller, K. L. (2009). Manajemen Pemasaran. Jakarta: PT Indeks.

Mandala, P., Maharani, E., \& Muwardi, D. (2016, Oktober). Citrus Marketing Analysis of Siam The Village Limau Manis Kampar District Kampar Regency. Jurnal JOM FAPERTA UR, 3 (2).

Manurung, S. E., \& Youlla, D. (2019, Oktober). Diversifikasi Pengolahan Buah Nanas Desa Galang Dalam Meningkatkan Pendapatan Petani Nanas. Jurnal AlIhlas, 5 (1).

Pandji, A. (2000). Manajemen Bisnis. Jakarta: PT RinekaCipta.

Setyarini, A. D. (2019). Tata Niaga Buah Nanas Tamban di Desa Mekarsari Kecamatan Mekarsari Kabupaten Barito Kuala. Banjarmasin: Universitas Lambung Mangkurat.

Syafril, Madayan, \& Bahri, S. (2020). Pemasaran Tempat Wisata Janda Desa Danda Jaya Kecamatan Rantau Bedauh Barito Kuala. Journal of Soscial Responsibility Project bu Higher Education Forum, 1-8. 